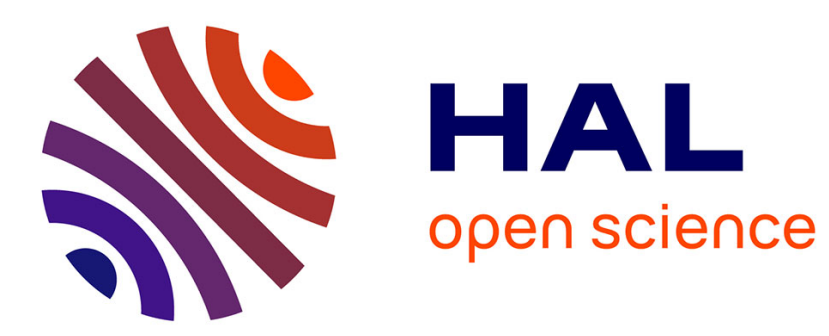

\title{
Global hunting grounds: power, scale and ecology in the negotiation of conservation
}

\author{
Kenneth Iain Macdonald
}

\section{To cite this version:}

Kenneth Iain Macdonald. Global hunting grounds: power, scale and ecology in the negotiation of conservation. cultural geographies, 2005, 12 (3), pp.259-291. 10.1191/1474474005eu330oa . hal00572154

\section{HAL Id: hal-00572154 \\ https://hal.science/hal-00572154}

Submitted on 1 Mar 2011

HAL is a multi-disciplinary open access archive for the deposit and dissemination of scientific research documents, whether they are published or not. The documents may come from teaching and research institutions in France or abroad, or from public or private research centers.
L'archive ouverte pluridisciplinaire HAL, est destinée au dépôt et à la diffusion de documents scientifiques de niveau recherche, publiés ou non, émanant des établissements d'enseignement et de recherche français ou étrangers, des laboratoires publics ou privés. 


\title{
Global hunting grounds: power, scale and ecology in the negotiation of conservation
}

\author{
Kenneth lain MacDonald \\ Department of Geography, University of Toronto
}

\begin{abstract}
Increasingly, large international conservation organizations have come to rely upon market-oriented interventions, such as sport trophy hunting, to achieve multiple goals of biodiversity protection and 'development'. Such initiatives apply an understanding of 'nature'-defined through an emerging discourse of global ecology-to incorporate local ecologies within the material organizational sphere of capital and transnational institutions, generating new forms of governmentality at scales inaccessible to traditional means of discipline such as legislation and enforcement. In this paper, I historicize debates over 'nature' in a region of northern Pakistan, and demonstrate how local ecologies are becoming subject to transnational institutional agents through strategies similar to those used by colonial administrators to gain ecological control over their 'dominions'. This contemporary reworking of a colonialist ethic of conservation relies rhetorically on a discourse of global ecology, and on ideological representations of a resident population as incapable environmental managers, to assert and implement an allegedly scientifically and ethically superior force better able to respond to assumed degradation. In undertaking such disciplinary projects, international conservation organizations rely on, and produce, a representation of ecological space as 'global' to facilitate the attainment of translocal political-ecological goals.
\end{abstract}

Then through the new-washed air, steaming with delicious earth-smells, the Babu led the way down the slopes-walking ahead of the coolies in pride; walking behind the foreigners in humility. His thoughts were many and various. The least of them would have interested his companions beyond words. But he was an agreeable guide, ever keen to point out the beauties of his royal master's domain. He peopled the hills with anything they had a mind to slay - thar, ibex, or markhor, and bear by Elisha's allowance. He discoursed of botany and ethnology with unimpeachable inaccuracy, and his store of local legends - he had been a trusted agent of the State for fifteen years, remember - was inexhaustible.

'Decidedly this fellow is an original,' said the taller of the two foreigners. 'He is like the nightmare of a Viennese courier.'

'He represents in petto India in transition - the monstrous hybridism of East and West,' the Russian replied. 'It is we who can deal with Orientals.'

(Rudyard Kipling, Kim) 


\section{Introduction: the past in the present}

Tn 1925, after failing in his bid to become Governor of New York, Theodore Roosevelt Ir headed 'East' to engage in what he felt marked him as a man; to hunt. Along with his brother, Kermit, his 'thoughts turned to central Asia ... this land [that] had always been the Mecca of our desires'. Like many Europeans in search of adventure, Roosevelt appealed to Rudyard Kipling to evoke the 'call of the wild' as one which no young man could resist. ${ }^{2}$ But in an interesting move, presumably tied to his father's influence on the rise of scientific conservation in the United States, Roosevelt was not content to legitimate his actions through the romance of adventure. 'Though hunting in itself is a great sport, without the scientific aspect, it loses much of its charm. Therefore, we decided that any expedition we made would be organized along scientific lines.' 3 These 'scientific lines', however, could not be dissociated from the locale of the science to which Roosevelt appealed. Following in his famous father's footsteps, Roosevelt's trip was woven through with a patriarchal politics of nationalism. ${ }^{4}$ Science and romance came together through the lens of nationalism to direct Roosevelt's travels through the Karakoram mountains and into central Asia, for '[t]he country was exceedingly interesting from a scientific standpoint, because no comprehensive American expedition had ever covered it, and there were to all intents and purposes no collections of the wildlife in our museums'. 5 This was a significant contribution in Roosevelt's mind, and he claimed that the expedition formed a 'link in the great study that is now in progress to determine the course of migration of animal life to this continent'. The expedition would promote the interests of American science by providing south-western Asiatic specimens so that 'our scientists in this country will then have at their disposal a more or less complete series' to test the Bering Straits land bridge theory. 'From this, in all probability, they will not only be able to prove their theory but also to work out many other interesting problems concerning variation. ${ }^{6}$

Move forward 80 years in time. A village called Hushe, nestled in the upper reaches of a valley in the same Karakoram Mountains that Roosevelt traversed, has landed a boon. This boon is international sport trophy hunting, a 'conservation-as-development' initiative that has brought a significant amount of cash into a community that has few other means of generating the stuff much demanded in an emerging market based economy. The use of international sport trophy hunting as a conservation incentive is far from being unique to Pakistan. In fact, it has become a foundational part of conservation planning within international conservation organizations. ${ }^{7}$ But it has brought the community within the sway of a new ideology of conservation. This ideology, brewed in the intellectual cauldrons of international conservation organizations, repositions community resources within a new system of meaning, alters the material realities of social relations within the community, modifies human-ecological interactions, and introduces a new form of governmentality that attempts to ground authority within the institutional arrangements produced through discourses of global ecology.

In this paper I use the case of Hushe to examine how market-oriented conservation interventions rely on an understanding of nature - defined through an emerging 
discourse of global ecology - to incorporate local ecologies within the material organizational sphere of such institutions, generating new forms of governmentality at scales inaccessible to traditional means of discipline such as legislation and enforcement. ${ }^{8}$ In addition, I historicize debates over nature in this region to provide a context for my claim that local ecologies are becoming subject to institutional agents of globalization through strategies similar to those exercised by colonial administrators in order to gain ecological control over their 'dominions'. What is happening in Hushe, I argue, is a contemporary reworking of a colonialist ethic of conservation that relies rhetorically on: i) a discourse of global ecology; and ii) ideological representations of a resident population as incapable environmental managers; to assert and implement an allegedly scientifically and ethically superior force able to respond to assumed degradation. Just as Theodore Roosevelt relied on an authoritative rhetoric of science and nationalism to justify his Asian hunting trip, international conservation organizations rely on and produce a representation of space in the Karakoram range as 'global' to facilitate the attainment of political-ecological goals. A number of authoritative discursive formations are used to buttress these representational tactics. Certainly one is the authority of scientific management applied to wildlife management. ${ }^{\text {P Others, }}$ however, include the representation of a degraded environment, a rapacious and ecologically ignorant local population, and the promise of 'development'. While the perceived facilitating effects of capital link these tactics, all are framed within a discourse of global ecology and the mechanisms through which it has emerged to achieve a position of global hegemony over the past 30 years.

The first section of the paper describes the project operating in Hushe and contextualizes it in light of the ways in which northern Pakistan has become the object of recent interventions by capital, the state, and international development organizations that both rely on and deploy representations of the Karakoram as environmentally and socially poor. The second surveys the discourse on biodiversity conservation as it emerged out of international organizations in the 1990s and its implementation in northern Pakistan. In the third section I argue that the implementation of a discourse of global ecology in Pakistan has - not inevitably, but by virtue of an uncritical acceptance of the dialectic between capital and modernity - reworked the networks of domination through which nature was constructed in an earlier colonial age. In the final section I discuss the transformation of nature-society relations implied by an intervention that paradoxically combines capital and nature as a mechanism for wildlife conservation.

\section{Inserting a capitalized nature: representation and intervention in the Karakoram}

\section{The project}

The village of Hushe is a small agro-pastoral community nestled in the upper reaches of a valley of the same name in the Karakoram mountain range of northern Pakistan. The Karakoram range lies in the disputed zone of the former state of Jammu and Kashmir 
(Figure 1). Most inhabitants live in small villages lining the tributary valleys to the Indus and Hunza Rivers, engage in subsistence agro-pastoralism, and continue to focus on internal modes of production, distribution and consumption. ${ }^{10}$ For centuries, the Hushepong have supplemented their cereal-based diet by hunting ibex (Capra ibex), a large mountain goat. In 1996 the World Conservation Union ${ }^{11}$ (IUCN) approached village leaders in Hushe with a plan. If the village leaders would agree to prevent villagers from hunting ibex, IUCN would pursue an agreement with the government of Pakistan and the Convention on International Trade in Endangered Species of Wild Fauna and Flora (CITES) that would permit the sale of permits for international hunters

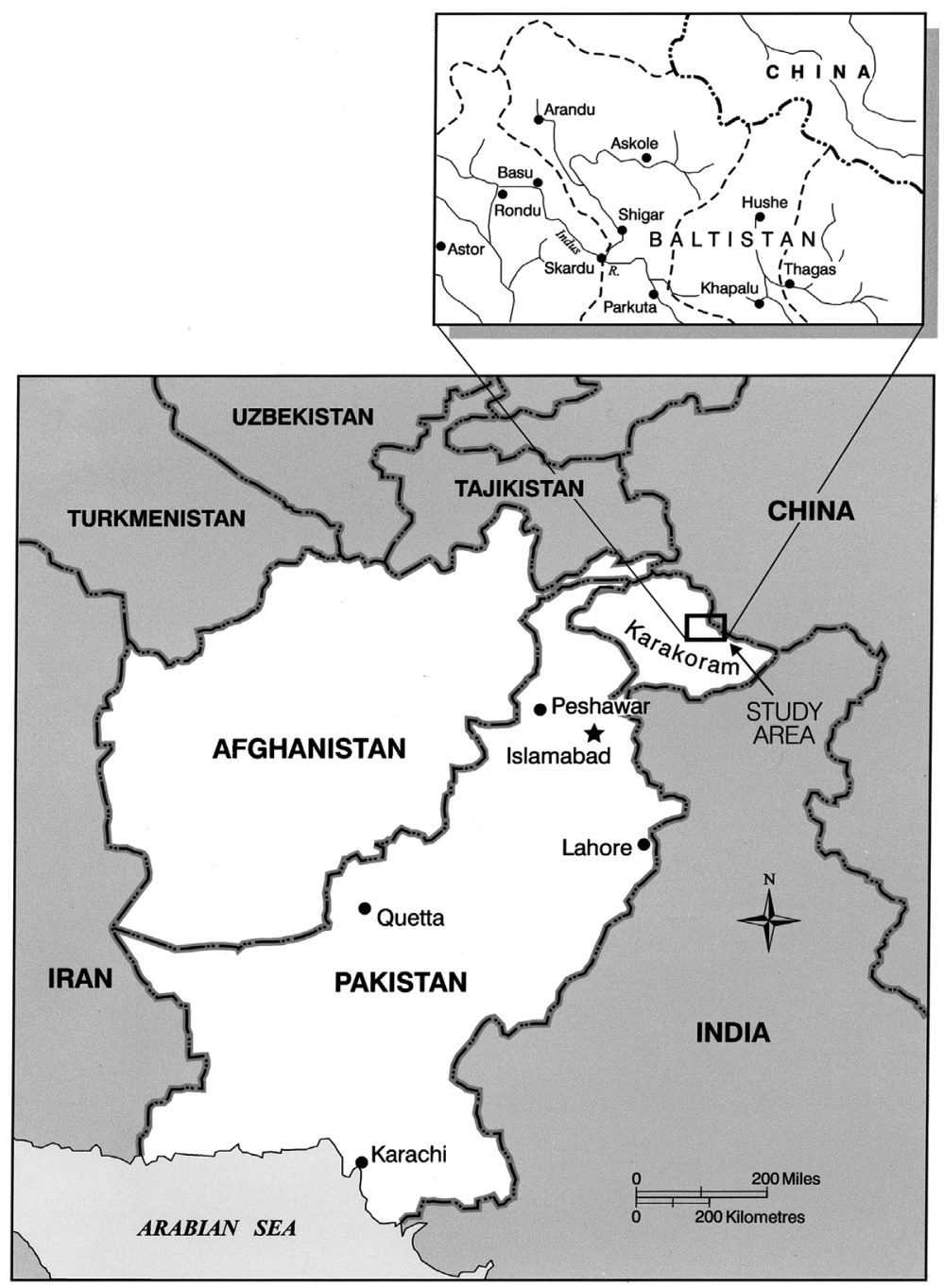

FIGURE 1 Pakistan and study area 
to stalk ibex on Hushe lands (Figure 2). Ibex are a valued trophy within the international hunting community, and the hope was that opening a limited market for the hunt would bring substantial funds into the community. Eventually the government approved a limited hunt, with the agreement that 75 per cent of the proceeds from the sale of the permits would go to the village while the remainder would go to the government. ${ }^{12}$ The marketing of permits takes place largely through the annual convention of Safari Club International, an organization of relatively wealthy hunters. ${ }^{13}$ Approval was also given by CITES to transport the carcass of a trophy animal to the hunter's country of origin. ${ }^{14}$ In Hushe, it was decided that during the first year, money from the sale of permits would be distributed equitably among the 100 village

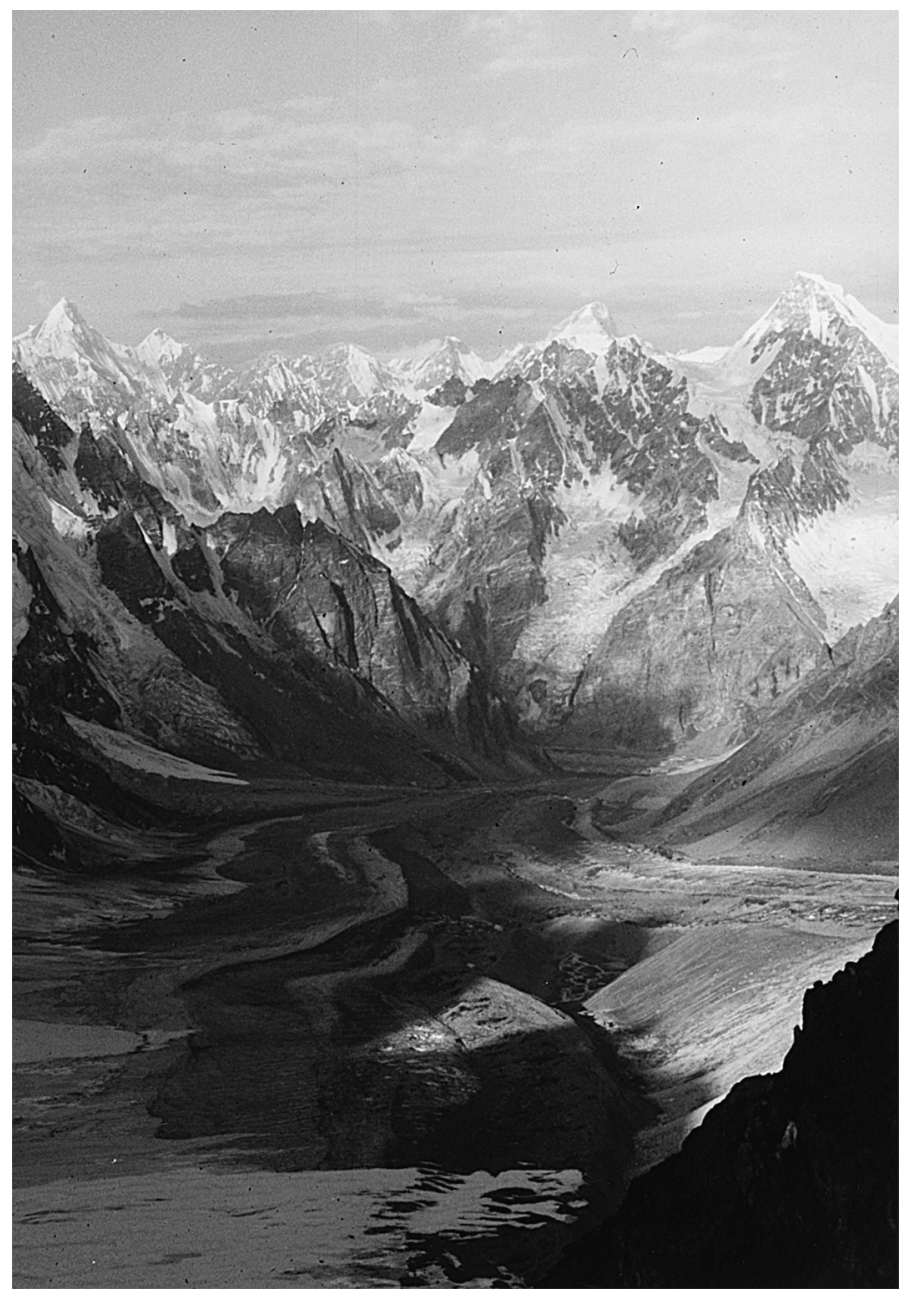

FIGURE 2 Typical Ibex habitat north of Hushe village. Ibex graze on the vegetation found in glaciated valley bottoms and on mountain spurs. 
households in an effort to convince all villagers of the value of refraining from hunting Ibex. ${ }^{15}$ Undoubtedly IUCN had multiple objectives in this project. One was certainly to try to protect what they felt was a declining number of ibex in the area, but another was to use this project as a demonstration of the links between conservation and development. It served as a way to show villagers that 'nature protection' could be used as a means to acquire the stuff of development, albeit through the medium of cash. Indeed this project was part of a wider $\$ 6$ million Global Environment Facility and United Nations Development Programme (GEF/UNDP) jointly funded initiative entitled 'Maintaining biodiversity in Pakistan with rural community development'. ${ }^{16}$ As the implementing agency, IUCN was responsible for helping villages to prepare 'village biodiversity management plans' in an effort to link the objectives of biodiversity protection with those of rural community development. The aim of this project was to 'demonstrate how conservation of Pakistan's biodiversity [could] be enhanced by providing rural villages with the technical skills to manage wild species and habitats for sustainable use and to assess the effectiveness of rural village management of natural resources'. ${ }^{17}$ This objective falls within a wider GEF/UNDP interest 'to test and perfect a new approach in conserving biodiversity, replicable both nationally and internationally' ${ }^{18}$

\section{Trophy hunting as eco-development}

The logic of relying on trophy hunting as a means to protect biodiversity is not difficult to grasp from the perspective of capital. Central to this logic is the subjugation of nature to capital and the use of that capital in the pursuit of 'development'. This form of ecodevelopment has certain pre-requisites. One of these is rooted in property relations and the control of access to property; another is rooted in desire. Perhaps it is easiest to start with desire. First is the desire of some international conservation organizations to protect elements of biodiversity that they deem to be important. Just as important, however, is the desire of some hunters to kill those very same elements of biodiversity, and their willingness to pay to do so. Third we have the desire of villagers, some of whom at least would like to acquire the long-promised benefits of 'development'. Within this logic, all of these desires can be satisfied by two things: (i) the acquisition and enclosure of 'state property' - the species, and (ii) the willingness of village authorities to provide access to land on which 'state property' resides (even though they do not see wildlife as state property). A single species is the key that holds all of this together. In the case of trophy hunting in Hushe, the 'boon' with which I opened this paper, that species is Capra ibex.

For villagers, ibex have long been both an instrumental and a symbolic resource. Those who can afford to hunt have historically relied on its meat as a supplemental source of protein, but, as with most species hunted for subsistence, all of its products are used (Figure 3). Ibex, however, is also a symbol of fertility, vitality and strength in the animist belief system that still underlies this Islamic community. Accordingly, when an ibex is killed, its essential organs-the heart, liver and kidney - are distributed to 


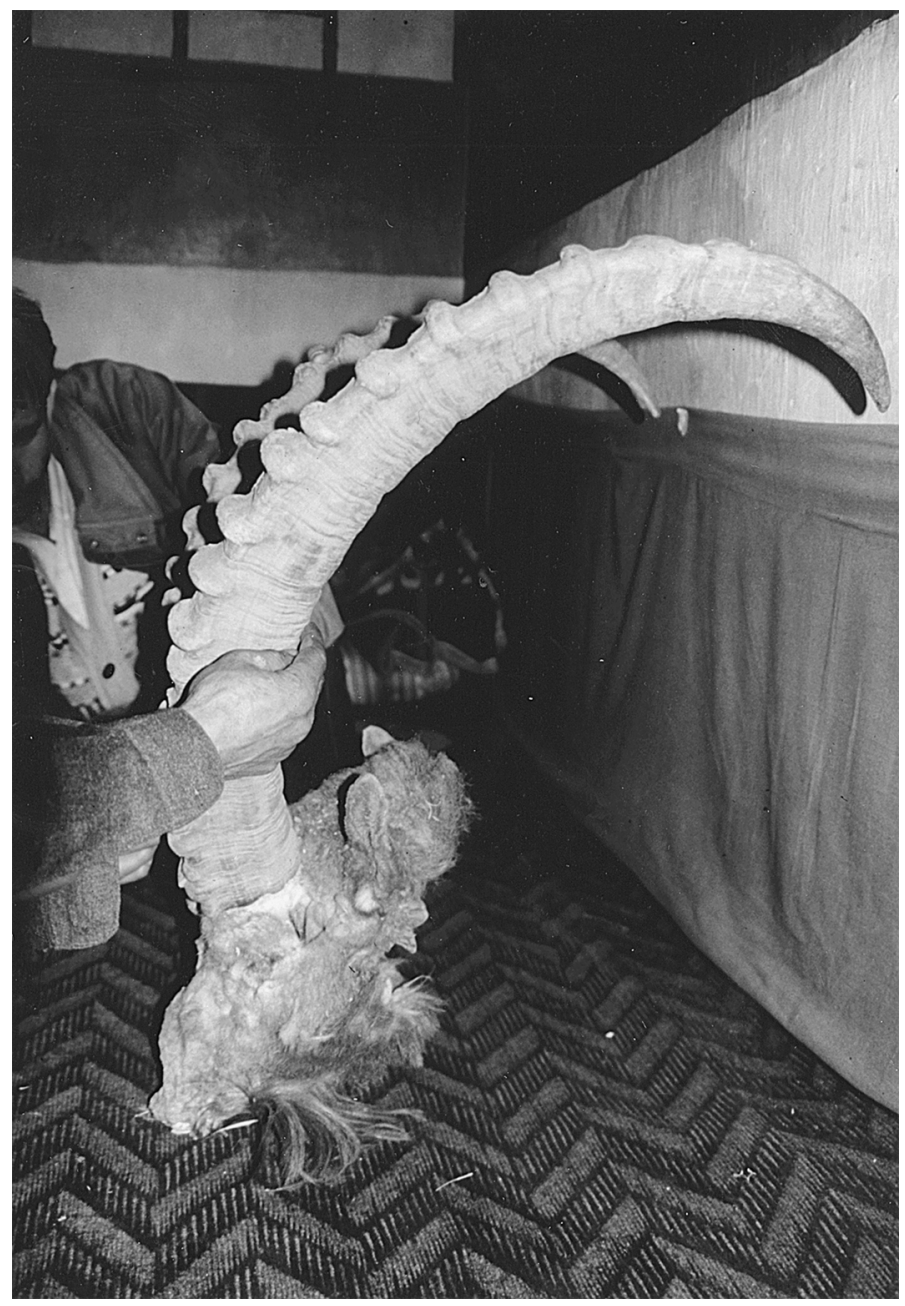

FIGURE 3 The head of an adult male ibex, approximately 10 years old. The meat from this animal was distributed within the village and the skin was made into a backpack for carrying grain.

people significant to the hunter as a means of wishing them good health and commenting on the continued significance of their authority. Ibex meat is also distributed amongst filial and fictive kin as a means of expressing a social commitment to their wellbeing and fostering strategic allegiances. Just as ibex have symbolic value for villagers, they also hold symbolic value for international trophy hunters. Far from being interested in conservation, trophy hunting is motivated by wildlife as an object of desire. This desire is not a purely individualized phenomenon, however, but is fed by a particular reward structure within a 'community' of hunters. International trophy hunting has status value which is reflected in the sanctioning structures of organizations like Safari Club International or the Grand Slam Club, which offer awards to hunters 
who, for example, kill all representatives of the subspecies of a particular species (the so-called 'world slam'), or who kill the largest individual of a particular species in any given year. The words of one American hunter who engaged in a trophy hunt in the Karakoram highlight the significance of the hunt in terms of status:

This will probably be one of the highlights of your hunting career, in that this is a very important trophy and everything, that very few people can claim to have come to this country to hunt. Years ago it was pretty big on the international scene, with a lot of kings and people of wealth used to hunt here quite a bit. Now it's opening it up to the average hunter. ${ }^{19}$

This statement implies that the value of the hunt resides in its exclusivity - facilitated through limited access to space and wildlife-and its association with a particular class and race status. The 'average hunter' referred to above clearly does not include local subsistence hunters. There is little doubt, however, that this hunt follows the logic of trophy collecting, of adding to 'the bag'. It is this structured desire that creates ibex as a value-added species, and international conservation organizations have been quick to appropriate that added value and use it to serve the ends of biodiversity protection. This internationalization of hunting does not happen without a demand for hunting opportunities on the part of wealthy foreign hunters - a demand wrapped up in constructs of the exotic and the legacy of the safari - but it is also grounded, at least in part, in the rise of environmentalism and conceptions of public good that challenge the activities of hunters closer to home. In North America, for example, participation in hunting has declined over the past 25 years. The reasons for this are multiple but can be loosely tied to a rising appreciation of the rights of non-human species. International trophy hunting, however, is on the increase, and this is reflected in a 71 per cent increase in the importation of foreign game killed by US trophy hunters since $1990 .^{20}$ No doubt this is fuelled by exoticism and the status derived from the sanctioned rewards of the 'hunting community', but it is partially also a flight from opposition. As trophy hunting faces increased opposition in North America and Europe, and as opportunities to hunt encounter increased restrictions, hunters, like multinational industries, flee to grounds where they can escape those restrictive conditions.

From a 'community' perspective, at least one motivation for village leaders to participate in the project was the chance to acquire the cash through which they could realize the long-promised material benefits of development. In essence, the implementation of sport trophy hunting provides the means for converting wildlife to a commodity with exchange value outside the community. Wildlife, then, becomes a source of direct income that can be used to acquire some desired benefits such as increased household income and the development of infrastructure. It is the promise of these benefits that is meant to provide villagers with a disincentive to engage in hunting. ${ }^{21}$ Increased household income or the benefits of social or physical infrastructure are taken as a measure of increased development so that wildlife, as commodity, becomes one basis of community development. Of course, this logic is grounded in inequity. It only works where there is a vast difference in the material conditions of those providing access to wildlife and those paying for the experience of the hunt. It is this association of wildlife with development, rooted as it is in inequity, 
which provides the leverage to emplace a new form of discipline in villages like Hushe. This 'new' form of discipline - what we might call enviro-discipline - relies on the intersection of capital and a discourse of global ecology to achieve its ends, and is supported by some conservationists who use understandings of prey-predator relationships to assert that the modifications of behaviour predicated on the capitalization of nature (assuming that they work) will lead to the maintenance of integral ecosystems and the protection of biodiversity. ${ }^{22}$

\section{Representations of environment and the facilitation of intervention}

The insertion of capital into the realm of 'nature' in northern Pakistan, outlined above, has not gone uncontested, but attention must be paid to the way in which a dominant representation of the Karakoram region has facilitated the ability of development and conservation institutions, as well as adventure tourism operators, to access the region. From the 1930s on the Karakoram has regularly been described as an area stricken by environmental poverty and ecological marginalization. Accordingly, people inhabiting the Karakoram have been represented as marginal, as lacking in knowledge or capacity to survive in their own environment. Butz ${ }^{23}$ provides a fascinating archaeology of knowledge of 'the Karakoram' which reveals a consistency of representation from the 1930s on, epitomized in a recent World Bank description that is little different from the depictions of British colonial administrators:

[A] cause of rural poverty is a restricted or declining resource base. People may not have access to land, or the land may be of such poor quality that existing low-capital technologies cannot provide an adequate income. This situation also characterizes the Northern Areas. The land base is limited to fan-shaped areas of flat or terraced land along rivers and some high, mountain-top pastures. The water supply is restricted to irrigation from snow or glacial melt because of very low rainfall. The soils are thin, and the whole natural environment is fragile. Livestock quality is poor, food for livestock is scarce, and crop varieties are generally low yielding. ${ }^{24}$

The reified Karakoram, then, is a place of environmental poverty, with an accordant 'primitive' lifestyle grounded in eking out subsistence from an inadequate environment. ${ }^{25}$ Such representations set up an empirical reality of the Karakoram as existing in a condition of lack or absence - a condition which can be dealt with through appropriate economic, technical and social interventions. While this representation emerges from particular ideologies of science associated with an age of imperialism, it continues to serve the interests of a number of institutions that, following an active period of external intervention during the colonial occupation of India, have made northern Pakistan the target of development initiatives. ${ }^{26}$ Environmental and social poverty combined with an assumed lack of institutional capacity, for example, underlay the basic operating assumptions of the Aga Khan Rural Support Programme (AKRSP), the first major development enterprise in the region, which began operations in 1983. Based on assumptions of inadequate social organization, the AKRSP set about 
establishing village organizations (VOs) - new social formations based on a process of electoral politics. Beyond the material consequences of development projects implemented through the AKRSP, the effects of which have been contentious, the main impact of the agency has been the resignification of the people and place of the Karakoram as subjects of development. This is evident in the insertion of the region into a new global regime of representation in which 'capital, science, and institutions of the state provide the signifying categories'. ${ }^{27}$ The AKRSP has also effectively facilitated the process of expert-based social intervention throughout the Karakoram. It is difficult to encounter a subsequent agency that has not used VOs and AKRSP Social Organizers as a route of access to villages, and as the mechanisms through which to introduce new technologies, innovations or programmes. Agencies including IUCN, WWF and UNDP, for example, have set up regional offices in the major market towns of the mountains over the past six years and have taken advantage of the advance work of AKRSP.

In spite of the activities of development agencies, the major infusion of capital into the Northern Areas over the past 15 years has been in the form of adventure tourism. Although the central Karakoram has been attracting professional travellers, hunters and 'explorers' since the mid 1800s, an incipient adventure tourism industry has experienced a significant expansion since $1989 .{ }^{28}$ Tourism in northern Pakistan is mainly a local articulation of global processes. ${ }^{29}$ Tourists, primarily Americans and Europeans, come either to see or to climb peaks deemed important in terms of their physical features (elevation, climbing difficulty), or their significance to some history or experience with which the traveller identifies. ${ }^{30}$ Not simply space, but space articulated through particular identity formations, then, becomes a consumable product. Socially, tourism has generated new forms of poverty and inequity in some village communities through intensifying social stratification and possessive individualism. None of this, of course, goes uncontested. Forms of resistance are evident within village communities, but the extent and forms of new capital, along with its institutional affiliations, subverts both the relevance and effectiveness of long-term adaptive practices. ${ }^{31}$ Adjustment certainly continues to take place, but is much more reliant on the recognition of an individual subject with particular interests, and the access of subjects to capital or power outside the local community. As Gupta makes clear, access to brokers is increasingly important in 'adapting' to the changes wrought by capital and modernization. Capitalists and development institutions are not blind to this and encourage these changes with some degree of consciousness. ${ }^{32}$ In the process they form convenient alliances with, and facilitate the emergence of, a new regional political elite who attempt to take control of 'development' and to 'modernize' local institutions. As a consequence, new innovations tend to follow a particular trajectory of power as they are introduced to villages, and it becomes much easier for nascent elites to consolidate power by controlling the flow and distribution of benefits through the regulatory management structures put in place by institutions such as the AKRSP and IUCN. While this is clearly apparent in interviews with local residents, development and conservation institutions continue to present their interventions as being in the interest of 'the community'. 'The community', however, is commonly treated as a monolithic body of subjects with uniform interests, rather than as a network of micro-power relations (and 
their effects) contextualized and bounded by the transformations introduced by regional, national and international relations of production. ${ }^{33}$

In many ways, the interests of an intensively capitalized global tourism market and large international conservation organizations intersect with the state in a struggle to define, represent and shape the present and future of the area. It is hard to say, however, that there is direct competition in this struggle, for many of the actors involved - the state, capital (largely in the form of adventure tourism agencies), and a variety of social movements - co-operate with each other as much as they compete. Despite this appearance of co-operation, however, these actors appeal to different cultural and political economies and rationalizations for their legitimation. Most, however, use a singular representation of the environmental history of the Karakoram, and benefit from their ability to refer to a capacity to contribute to environmental protection and 'development' through either generating an awareness of or directly intervening in the preservation of global biodiversity. ${ }^{34}$

\section{Global ecology, biodiversity and the cultural politics of environmentalism in the Karakoram}

The extension of international conservation interests in northern Pakistan described above is directly related to the production, and circulation, of a discourse of global ecology. This discourse emphasizes the protection of biodiversity, but it is very much grounded in the legitimating value of science and the ontological status of ecology that incorporates distinct political environments into a global commons. The dominance of 'global ecology' has come about in part through the power of transnational institutions to produce and circulate knowledge, and their control over access to funding that local governments can use to pursue development goals. This network of power sets up structural conditions through which a discourse of global ecology finds its way into national level institutions and emanates from them through regional and local level nodes until it takes on a material reality in the form of specific projects in localized environments.

Part of the ability of international agencies to garner support for their activities stems from their history of mediating international environmental relations. ${ }^{35}$ International organizations such as the IUCN appeal to their non-governmental status to assert a nonpartisan position. But what allows these agencies to transcend nationalist interests is the effective way in which they have produced environmental problems as global problems within the popular imagination. According to David Takacs, who has traced the development of the term, the idea of biodiversity has been central to this production, for it has effectively collapsed a range of environmental concepts localized terms like 'habitat' or 'ecosystem', for example - into one essential subject, the protection of global biodiversity. 'Under the rubric of biodiversity, these terms are repackaged to unite amorphous, diverse endeavours in a streamlined, do-or-die conservation effort with biologists at the helm. ${ }^{36}$ Biodiversity, then, has become the emblem that dominates the perception of the ecological dilemma as it effectively reifies 
a global image of an interconnected web of life. This interconnection rhetorically transcends concerns of boundaries and ties all humans into a common goal of ecological maintenance at a global scale. The focus on biodiversity, then, is central to a discourse of global ecology and has gained prominence through ecology's assertion that human survival relies upon the maintenance of biodiversity. This problematizing of the biological (i.e. its relevance to human and economic survival) has lead to the emergence of a global bio-politics, most effectively expressed through the rise of an institutional ecology manifest in global organizations such as IUCN, WWF, UNDP and GEF. Through the rise in a particular variety of environmental awareness in the West one dominated by concerns of biodiversity protection - and positions of political influence, these organizations have established themselves as watchdogs, and have effectively used their authority to define global environmental problems and their solutions, and to influence national politics and decision-making. ${ }^{37}$ In many cases, such agencies act as mediators between national governments and supranational agencies, and influence the design of international scientific research programmes that frame the official environmental agendas of many governments in so-called developing countries. $^{38}$

At a broader societal scale, institutional environmentalism has also contributed to what some have called the 'age of ecology' or the emergence of an incipient ecological world-view. Jamison, for example, recognizes that biodiversity and the contemporary concern with global environmental problems have been produced by highly organized institutional endeavours that incorporate national planners and local communities into a complex politics of techno-science. ${ }^{39}$ This politics promotes the preservation of biodiversity not simply as an end in itself but as the route to the production of wealth and the attainment of development. However, the degree of public awareness that adds to the currency of this endeavour also relies on some similarly highly organized body engaged in 'translating expert discourse into politics, and also recombining specialist expert knowledges into policy-oriented packages'. ${ }^{40}$ This, Jamison says, has been effectively accomplished through the marketing strategies of large international conservation organizations that have helped to create a new phase of institutional environmentalism in which global environmental processes have assumed priority over local ones and helped to produce and popularize the idea of a global commons. ${ }^{41}$ Through the representation of environmental problems as territorially transcendent, transnational NGOs have assumed an enhanced political significance and have come to play a crucial role in 'the transnational arenas where agreements are negotiated over the exploitation of the "global commons". ${ }^{42}$ Their ideological positions on environmental problems also form the basis for policy measures, and, through a network of regional offices, they deploy expertise and conduct the research that produces knowledge used in global environmental discourse, including the construct of a 'global commons'. ${ }^{43}$ Of course this does not exist in isolation from the nationalist interests expressed by the administrations of nation states. From both perspectives, the threat to biodiversity, particularly in developing countries, is not seen merely as a problem that threatens the biological potential of human beings. It is also one that threatens the existing social order. Hence, agencies like IUCN and WWF - taking their 
cues from the science of ecology - spread the mantra of biodiversity, and trade in the techniques through which a normative and uniform management of biodiversity can be exercised around the world. ${ }^{44}$ Yet they are not alone in enacting this modification. The intersecting interests that underlie support for these projects have significant implications for the everyday lives of people and ecologies in places such as Hushe, the example of which I return to below.

\section{Biodiversity: institutional sanctioning and the appropriation of 'the local'}

The direction of policy through transnational environmental institutions described above is manifest in projects such as 'Maintaining biodiversity in Pakistan with rural community development'. Recall that the motivation for this project, and presumably the availability of funds, was tied to GEF's desire to develop and test an approach to biodiversity protection that could be replicated internationally. This desire for international replication is fed by an understanding of biodiversity as ontological, as something that transcends the frictions and problematics of context. The project took shape in early 1991, as the result of an IUCN and AKRSP reconnaissance mission to 'examine the feasibility of a community-based natural resource management project'. ${ }^{5}$ This mission was meant to address the need to conserve what were understood to be 'fragile ecosystems' in the Northern Areas of Pakistan. A project proposal was submitted for GEF funding through UNDP. This proposal was approved, and implementation of the pilot project began in 1995. An analysis of project documents reveals the ways in which representations of the Karakoram and a discourse of global ecology align to structure the aims of the project which, according to Ahmed and Hussain, both IUCN-Pakistan employees at the time, were to: (i) demonstrate how conservation of biodiversity can be enhanced by providing rural people with technical skills; (ii) demonstrate how local institutions can manage wild species and habitats for sustainable use; and (iii) assess the effectiveness of rural village management of natural resources. ${ }^{46}$

With these objectives in mind, the project framework appropriates the language of participatory development and collaborative management to articulate a process that claims to put "local people in the "driving seat", transferring control and building their capacity to conserve and sustainably use natural resources. This conservation approach becomes the agenda of the local communities, the government institutions, and the local NGOs, while the donors assume a supporting and facilitating role. ${ }^{47}$ Within the proposed plan, a Project Management Committee (PMC) oversees IUCN, AKRSP and Government of Pakistan personnel working together to implement the project. In practice, the PMC selected a set of sites on the basis of criteria that were seen to influence the sites' potential for success. ${ }^{48}$ Selected villages were then approached in a series of three dialogues which culminated in the development of a village biodiversity management plan and the signing of a terms of partnership between the project and the VO for implementation and future cooperation. ${ }^{49}$ It is in the development and 
implementation stages that the transfer of skills and capacity building is meant to occur. Village management plans focus on a particular 'management activity' selected by the $\mathrm{VO}$, and 'identify an important resource that they wish to conserve as an agenda for biodiversity conservation, and define a regime for its sustainable use'. ${ }^{50}$ Yet, in this project, we can identify a strategic environmental initiative in which development assumes the forefront, for 'in preparing this project, it is expected that they [VOs] will develop biodiversity management plans for purposes like sport hunting, game bird hunting, management and use of medicinal plants and ecotourism'. ${ }^{51}$ What this statement implies is that 'involving local people in biodiversity management', 'putting local people in the driver's seat', 'providing local people with the skills to appropriately manage their resources', and 'demonstrating how local institutions can manage wild species and habitats for sustainable use' actually means commodifying wild resources and inserting them into global circuits of exchange. Despite the language of participatory development and collaborative management that is deployed within the project documents, the goals and objectives articulated here and the structure of project management continue to relegate various community interests to post facto positions, if they are taken into consideration at all. For example, the project structure ignores the reality of power relations in the region. No community members were involved in the design of the project, and the document presupposes 'community' to be a homogeneous body of interests, assuming the potential for uniform input and distribution of any resulting benefits. ${ }^{52}$ This is not at all unusual within conservation projects. Despite recent work that advocates the promotion of collaborative management and participation in conservation as development programmes, long-term social research indicates that attempts to implement such goals have consistently failed. ${ }^{53}$ Much of this can be seen as resulting from the absence of good social research capacity in the implementing agencies, but attention must also be paid to the low priority given to social policy goals within the implementing institutions, which are staffed primarily by natural scientists or economists. ${ }^{54}$

The effects of this lack of attention to social research and the assumptions of social capacity inherent in the project are revealed in the project proposal, which very clearly identifies mechanisms to address the first two objectives but fails to do so for the thirdassessing the effectiveness of rural village management of natural resources. It is this oversight that reveals the tokenism of the participatory rhetoric deployed in this project; far from being an oversight, the reasons for this absence can be found in the project justification statement which identifies the 'need for the project: At present, there are few incentives for rural people to maintain or manage renewable natural resources sustainably. ${ }^{55}$ In this short statement, the authors of the project evacuate the possibility of a sophisticated knowledge of local environmental processes on the part of local residents and assume a priori that village management strategies are ineffective in conserving resources, hence relieving them of the need to address the third stated objective. This assumption is grounded in a belief that:

Government agencies have a very limited capacity to enforce wildlife laws, making it virtually impossible to control rural people's use of wild resources - especially when they need these resources to meet their subsistence requirements. The problem will become more acute with increasing human population if 
mechanisms are not provided for rural people to acquire the technical skills to manage wild resources. An alternative approach is needed that involves rural people in the solution rather than considering them the cause. $^{56}$

This project is grounded in a set of basic, and unwarranted, assumptions. The first is a set of assumptions about biodiversity. Nowhere in the project document is biodiversity actually defined. Indeed, the document opens with the redundant statement that 'Pakistan's biodiversity is diverse'. For most of the document, biodiversity is expressed in terms of the fairly typical charismatic mega-fauna species that 'merit enhanced protection' and plant species 'that have potential economic value'. Both of these are said to be in decline because of hunting pressure, which is being exacerbated 'because natural habitats are being converted to agricultural production at an ever increasing rate'. ${ }^{57}$ These classic 'blame the villager' tropes do not stand up to scrutiny. This is not to say that they are not true, but that there has been no quality longitudinal research to demonstrate them one way or the other. The Karakoram region has never been subject to a detailed floral or faunal survey, so there is no benchmark against which to judge current numbers or their status. ${ }^{58}$ Beyond that, the habitat destruction and overgrazing arguments do not hold for the species identified in the report. For the most part, these species exist above the level of permanent cultivation and most indicators suggest that, as a cash economy expands in the region, pasture use is actually decreasing in the Karakoram rather than expanding. ${ }^{59}$ Finally, the assumption of increasing population in the upper reaches of Karakoram valleys is challenged by demographic research in the region that points to a pattern of population stability over the past 100 years. ${ }^{60}$ These assumptions regarding the state of biodiversity are compounded by assumptions about the role of community institutions in the management of resource use, relations between rural villages and government, community social structure and local views concerning nature. It would be a daunting task to expose all the flaws in these assumptions. Suffice it to say that none of the organizations associated with this project has conducted detailed social or bio-geographical research in any of the communities involved. Nor have they spent sufficient time in these communities to have any accurate sense of agro-ecological practice, community-based conceptions of nature, or the role of community institutions in 'managing wild resources'. Consider, for example, the rationale for adopting a 'community-based approach to biodiversity protection' - that 'the earlier approach of conservation through legislation and keeping local communities out of resource management, have failed'. 61 This is an example of seriously overestimating the salience of government in the daily lives of rural villagers. When the most 'government' that people usually see are the police or the army, neither of whom show much regard for local resources, it has been rural villagers who, far from being excluded, have for centuries been the primary 'environmental managers' in the central Karakoram. From the perspective of the project, however, this does not matter, for its ultimate assumption is of a people without appropriate environmental knowledge or skills. And its ultimate goal is to demonstrate its 'relevance to and furtherance of GEF objectives':

in relation to the principal criteria under the Biodiversity sector of GEF, the project will conserve ecosystems and threatened species through development of village biodiversity management plans with sufficient incentives to sustain their management of resources. 
The model evolved through this study for rural villages to integrate management of their environment with their economic development activities will be very useful. Enhancement of government and NGO capacities to advise and assist rural communities to manage wild resources sustainably will ensure replication to other regions of the country and abroad.... The project will screen plant material that has potential international economic value and ensure that rights to use those resources are retained in Pakistan. The commercial benefits of these indigenous materials will be demonstrated to villagers. ${ }^{62}$

These statements contain an implicit assumption that underpins the entire proposal: that the practices of 'rural people' are contrary to the interests of biodiversity protection; as government cannot act coercively to meet the project's goals, the means for people to discipline their own activities must be established. This is to be achieved in two ways, although they are not stated as such in the proposal: (i) through the realization of the exchange value as opposed to the use value of plant and animal biomass; and (ii) through the transference of skills meant to manage wild resources in accordance with production goals determined by exchange value.

It is in this equation of biodiversity with material wealth, and the potential for economic gain, that the interests of the state, environmental institutions and capital align to affect the day-to-day lives of rural villagers. The key, of course, is that, to link biodiversity protection with development, 'nature' must be seen as something with exchange value that exceeds use value. Trophy hunting is one mechanism through which to make this link, but it is also part of a cultural politics of 'global ecology' that has specific local effects. Here, I follow Escobar's description of cultural politics as 'the process enacted when social actors shaped by or embodying different cultural meanings and practices come into conflict with each other'. However, I qualify this to say that cultural politics need not involve conflict; that 'interaction' can act as a substitute for conflict. $^{63}$ According to Escobar, culture becomes political when 'meanings become the source of processes that, implicitly or explicitly, seek to redefine social power ... This cultural politics unsettles familiar understandings and practices of nature, as it attempts to wrest away local ecologies of mind and nature from entrenched networks of class, gender, cultural, and ethnic domination. ${ }^{, 64}$ Below, I assert that conservation interventions in Hushe set in motion processes that both implicitly and explicitly seek to redefine social relations by asserting that biodiversity can be saved through a realization of the exchange value of ibex. Far from being isolated events, however, such processes are occurring across the Northern Areas with the intensified activity of international conservation organizations and the convergence of interests between those NGOs and multinationals - international hunt clubs, say, or tourism corporations - that would cloak themselves in 'green'. As I have pointed out, however, in the absence of data to demonstrate a decline in ibex, or any knowledge of local human-environment relations, the capacity to intervene relies upon the use of historical cognitive resources to assert an environmentally incompetent 'native'. To understand the contemporary cultural politics of conservation in northern Pakistan, then, we need to turn to the ideological representations of people and place produced during the British administrative control of Kashmir - a period when 'nature' was also contested and when the trope of the 'rapacious native' was used to legitimate the colonial enclosure of space in the interest of conservation. It is useful to trace this 
history to understand the positioning of today's 'rural villager' as an incapable steward of the local environment within the discursive formations of international conservation organizations operating in the area. ${ }^{65}$

\section{Claiming history, claiming trophies and claiming space}

There is little new in the connection between representations of the 'rapacious native', the rhetoric of conservation, and the enclosure of space in Kashmir. From the point at which Kashmir was opened to British officers in the mid-nineteenth century, hunters established a relation between the ability to control access to space and securing the right to hunt. Tyacke, for example, notes:

to secure the shooting rights in a nala [stream valley], you must be the first in the nala. The pitching of a tent in it, if you are not yourself present, gives you no title, and if you find a tent pitched without an owner present somewhere in the nala you have a perfect right to strike it, and claim the shooting. ${ }^{66}$

Though it is difficult to get any sense of just how much hunting occurred before the end of the nineteenth century, declines in game populations were witnessed as early as 1890 and regulations put in place to limit the exploitation of certain species. Lawrence, for example, notes that the state introduced rules for the preservation of Kashmir stag (Cervus elaphus hanglu), ibex (Capra ibex) and musk deer (Moschus moschiferus) in 1890, and that the few reserves maintained by the state, within which hunters needed special permission to shoot, were important in retarding the extinction of game. ${ }^{67}$ Like others, however, Lawrence does not see hunting by Europeans as primarily responsible for the decline of game. Rather, he locates it at the feet of 'natives' and blames the 'drop in hinds' on Kashmir villagers. He does not completely excuse Europeans. 'Europeans, who ought to have known better, have occasionally disgraced themselves by stagdriving in the snow, and one case was reported a few years ago when a person killed fourteen stags, which were driven through the deep snow, past the chair on which he was comfortably seated.' 68 Here, however, he sets up a moral difference between Europeans and 'natives'. 'Natives' cannot be expected to know the effects of their actions on wildlife populations, but Europeans should be above such matters. Lawrence, however, is not comfortable with the ability of Europeans to constrain their ambitions and recommends that the state regulate the sport:

Though the state is anxious to co-operate in game preservation, and recognizes that it is the sport of Kashmir which chiefly attracts the European visitors whom His Highness the Maharajah welcomes so hospitably, I do not think that game preservation will be placed on a satisfactory basis until an association is formed for the purpose of controlling sport in Kashmir. If some association were formed, a healthy public opinion would be created, which would check wholesale slaughter of game and all unsportsmanlike behaviour. The question is of considerable importance, as Kashmir and its neighbouring mountains have afforded health and excitement to British officers serving in India, and it would be a matter of serious regret if game were exterminated by the selfish and ignorant conduct of the fin de siecle sportsman, and if the grand stalking of the Kashmir mountains, so congenial a relaxation to the soldier, became a thing of the past. $^{69}$ 
Lawrence's demand for associations anticipates the formation of hunting societies in the early twentieth century. ${ }^{70}$ More importantly, however, his appreciation of reserves disguises an epistemological break between the 'noble hunting ethic' of the European sportsman and the crass brutality of the local subsistence hunter. This understanding of difference was not unknown in Europe or America, where the basis for distinction was largely class. The campaign for trophy hunting led by Roosevelt and by the Boone and Crockett Club in early twentieth-century California, for example, was a classic example of a reform movement with 'an interlocking ethnic, class and regional agenda'. ${ }^{71}$ This movement sought to distinguish and eliminate subsistence and commercial hunting while codifying the rights of trophy hunters. While legislation was used to secure these goals, the purchase of exclusive hunting preserves was also implemented to limit the access of 'undesirable' hunters. In Kashmir, even though some Europeans resisted regulations, the ideology of law was structured along racial lines so that when legislation was established, white Europeans were designated sportsmen whereas 'natives' were either shikaris (hunting guides for whites) or 'poachers'. Subsistence hunting, in effect, became criminalized in the interests of a race- and class-based trophy hunting. To be sure, those hunters who supported the implementation of regulations were defending their own manner of hunting on the grounds of a superior morality, and laying the blame for wildlife decline at the feet of the 'indiscriminate hunting of natives', who were seen as incapable of possessing a conservationist ethic. This construction of the 'rapacious native' gained popular credence through the publication of 'bag books' in the nineteenth century and is summed up well by Arbuthnot:

Sport in Kashmir is, alas! not what it used to be; the game is not nearly as plentiful as it was a few years ago. This regrettable state of things has been brought about chiefly by the natives, who kill large numbers of animals in the winter to provide themselves with food; and also sad to relate, with a view to selling the heads to so-called sportsmen, who visit the country in the summer, but are too lazy to do the shooting themselves.

The game laws recently established will, it is hoped, put an end to most of this; they also restrict the numbers of each description of game to be shot by any one person. It is a pity these game laws had not been brought into force many years ago, but if properly enforced now, they may yet be in time to save one of the most beautiful shooting grounds in the world; all sportsmen who go to Kashmir should do their best to act in concert with the 'Durbar', and report any breach in the game laws which may come under their notice. There is only one alternative and, should the laws prove a failure, it is quite possible that one may have to rent a nullah in Kashmir as one has to do a moor in Scotland. ${ }^{72}$

As Neumann has observed in Africa, these big-game hunters were not only setting their style of hunting apart from, and as superior to, the subsistence hunting of 'natives', but were defending it against 'active public criticism [and regulation] at home'. ${ }^{73}$ Many were certainly in favour of regulations, but only regulations that protected their rights, while those that blocked access to hunting grounds were publicly criticized. With the exception of Lawrence, for example, few supported the exclusive preserves that were only available to the maharajah and select company. But almost all Europeans saw 'the native' as 'to blame for the diminution in sport'. ${ }^{74}$ Aside from the implicit racism in these 
statements, the interpretation of 'native' blame for a decline in wildlife does not stand up under scrutiny. Few books, for example, make mention of the fact that 'natives' were prohibited from owning guns. ${ }^{75}$ Though some certainly did own guns, few had the cash to purchase ammunition, let alone the time to devote to indiscriminate hunting.

A more likely explanation for the decline in wildlife, and one that may well provide a preliminary route into understanding population dynamics as they affect herds today, is the political structure of Kashmiri game laws. While the laws covered the state as a whole, for all practical purposes they only applied to Kashmir proper and the domains of the minor rajahs of Baltistan were excluded from the laws. Hunting in those valleys was at the pleasure of the minor rajahs. Given this exception, it is not surprising that Baltistan was considered the 'heart of ibex country', and few 'sahibs' seem to have consulted the local rajas for permission before staking their claim to a nala. The regulations also limited the number of animals that could be shot by a licence-holder. While for individual species these seem low (e.g. the 1914 allowance was two markhor and three ibex), a single 60-rupee licence sanctioned the killing of 35 large mammals in total (Figure 4). Beyond that, some species that are now part of the catalogue of protected mega-fauna were regarded as pests and not subject to limits. These included snow leopard (Uncia uncia) and black bear (Ursus thibetanus):

Rewards are given for killing vermin to license-holding sportsmen by the Game Preservation Department. @ Rs. 10 for leopards (snow and common), Rs. 5 for leopards (cubs), Rs. 10 for wolves, wild dogs, lynx; Rs. four for carrion, crow and cormorant and other fish vermin. Also Rs. 5 may be given for others doing damage on trout waters at the discretion of the Game Warden. ${ }^{76}$

In addition, a caveat in the legislation made it possible for the 'sahib' to purchase a 'hindsight' licence to cover any excess animals that may have been 'inadvertently' shot during the trip. Finally, monitoring of the regulations was left up to the shikaris in the sahib's employ. Given that the shikari's livelihood was dependent upon both payment and recommendations from his sahib employer, it is doubtful that a shikari would act to report his employer to the state authorities. The oppressive domination of the Muslim population by Hindu bureaucrats would make it even less likely that shikaris (predominantly Muslims) would turn in their employers. ${ }^{77}$ Of course these are all hindsight observations that might help to explain declines in wildlife over time. The sahibs needed no such observation. They had an explanation for wildlife decline grounded in an epistemology of the 'native'. And in many ways, not much has changed since. 'Natives' continue to be blamed for wildlife decline. In a recent National Public Radio program, broadcast in the US, both the commentator and a WWF representative cited subsistence hunting as the cause of wildlife decline. In relation to the ibex, 'Richard Garstang of WWF says this subsistence hunting was so widespread it was threatening to wipe out species. ${ }^{, 78}$ Notably, Garstang is neither an anthropologist nor a wildlife biologist, but a conservation marketing agent, employed by both IUCNPakistan and WWF-Pakistan, who has been largely responsible for promoting the concept of sport trophy hunting in northern Pakistan and marketing it among large international hunting organizations. 


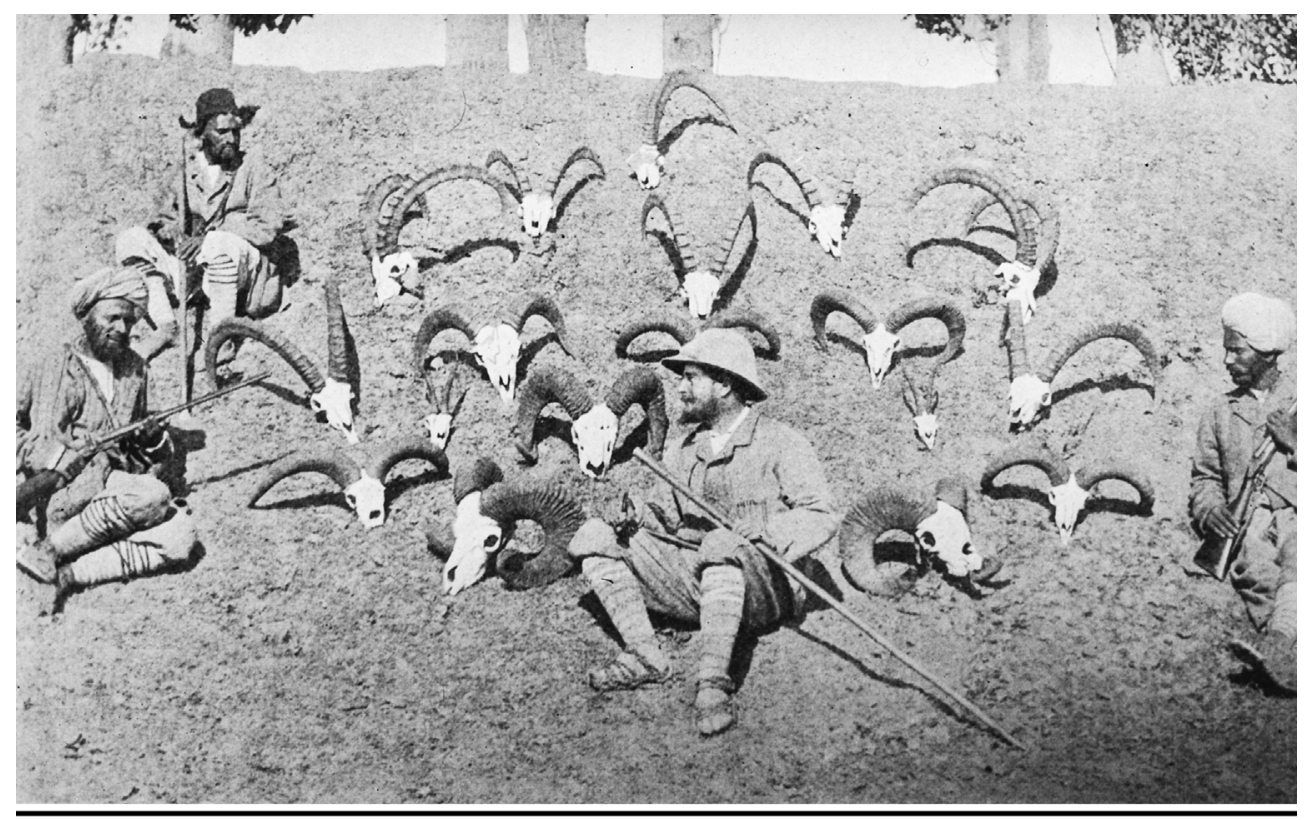

PORTRAIT OF AUTHOR WITH SHIKARIS AND TROPHIES.

FIGURE 4 Large mammals continued to be hunted in large numbers in the Karakoram until the end of British rule in 1948. This photograph displays the 'bag' of a hunting trip by Capt Frederick Adair in 1898. (F.E.S. Adair, The big game of Baltistan and Ladakh, a summer in high Asia: being a record of sport and travel in Baltistan and Ladakh (London, W. Thacker \& Co., 1899), frontispiece.

\section{The social and spatial effects of a capitalized nature}

Explanations for why representations of the 'rapacious native' are so durable can, I think, be found in their lasting usefulness for the needs of governance. Under a colonial regime, they were used to legitimate attempts at environmental regulation, and they continue to buttress contemporary efforts to protect wildlife. These contemporary efforts, however, are grounded in a realization that colonial and postcolonial regulations have not worked. They certainly do not stop subsistence hunting, nor do they stop the trophy hunting of local administrators, or the helicopter supported hunting of army troops stationed along the borders of Pakistani-held Kashmir. In the eyes of conservation NGOs, however, these regulations do not fail because they are flawed in themselves but because the government has no way of enforcing them in the 'remote' territories inhabited by the species they are designed to protect. The solution, then, from the perspective of spatially distant interests is not to do away with the legislation, but to find an effective mode of surveillance and monitoring. This is where the role of capital and trophy hunting fill the gap. Within colonialist ideologies, wild species were the property of empire and demanded the protection of imperial structures. The rhetoric of international conservation NGOs, however, inserts these 
species into a new regime of space. Now, these same species form part of the global commons and demand the protection of global structures. This commons needs to be managed - no longer for empire, but for the sake of the planet - and it is the tools of conservationist science that facilitate this management. What has changed, then, between colonial times and the present is not so much the discursive bases for a perceived decline in wildlife, nor the desire to protect large game species, but beliefs about the effectiveness of various means through which conservation can be achieved. It is in the search for new means that we find the logic behind the ideological rhetoric of 'conservation as development', or eco-development. If the subjects of development who occupy a targeted area can be convinced that conservation will bring the promise of desired development, this promise can then be used to extract a commitment to the goals of conservation. The resurrection of trophy hunting in northern Pakistan is one means that international conservation NGOs have recently begun to use to make this link. A discourse of global ecology and the related vocabulary of accounting, management and control, however, directly inform these projects. In many ways, the underpinning logic of such projects relies on a faith in the disciplining effects of wage labour capitalism similar to that found near the end of the British colonial era. Particularly in the case of trophy hunting, the conversion of subsistence biomass to potential accumulative capital is intended to exercise a form of ecological discipline. Operating through the social structure of the community, this disciplinary restraint is meant to modify the behaviour of villagers and make them conform to a set of behaviours prescribed by the demands of an external world-view of capitalized nature.

This attempt to introduce a new form of disciplinary restraint is salient to the cultural politics of nature in Hushe. In essence, trophy hunting is unsettling the familiar by extracting local ecologies from entrenched networks of class, gender, cultural and ethnic domination. It acts, along with other interventions, to situate local ecologies within new social and spatial contexts of domination, and to reorient exclusionary practices in face-to-face communities. International hunters and conservation NGOs, for example, proclaim an ethic of 'true' conservation as they facilitate the means through which game is assigned a monetary value. By doing so, however, they effectively remove resources from local control and management and situate them within the domain of national and international institutions. The motive is much the same as that of the British Indian administration which encouraged the Maharajah of Kashmir to establish hunting preserves and forbid villagers to own firearms. There is, however, a difference. It is now capital that makes this demand, rather than legislation backed by the sheer power of force. Capital, however, also requires the power of social and physical force to enforce its dictates and minimize the resistance of those who object to new forms of domination. It finds this new force not only in the sanctioning power and policies of global and national institutions, but also in the social pressure of those who stand to benefit from the proceeds of hunting (shop owners, guides, etc.). Capital is able to take advantage of the fact that communities are not bodies of homogeneous or uniform interest but social groups with a web of common and contradictory interests, particularly in an age when practices of modernization have encouraged the liberal ethics of individualism over communitarianism. ${ }^{79}$ 
But such fragmentation within communities, and the various trajectories of power through which particular groups can appropriate the benefits of interventions, is rarely if ever addressed in the documents of international conservation NGOs. Rather, IUCN assertions that 'sustainable use initiatives' such as the trophy hunting scheme implemented in Hushe represent co-management, or community-based resource management, are undermined by the historical and contemporary linkages of trophy hunting to processes of colonialism and globalization. Indeed, a case can be made that the degree of 'community' engagement in the management of local ecologies must be understood in the context of its connections to, and relations with, a wider global political economy. This does not seem to be apparent in the writings of conservation NGOs. Nor do they seem versed in local conceptions of 'community management'. It is difficult to appreciate how trophy hunting, for example, represents community-based management when the very conception of the environment that is to be managed via transferred skills is not grounded in an understanding of local conceptions of nature, diverse and hybrid though those may be. Rather, it is steeped in the vernacular and logic of conventional resource management that is derived from locally unfamiliar circuits of knowledge production. To take the case of Hushe as a simple example, existing human-environment relations have not been studied. And the forms that management can assume are now being structured by a community that has been extended to include nation-state governments, transnational institutions and the interests of capital, situated in a host of global sites.

Rather than emphasizing and strengthening community processes, one of the primary consequences of a capitalized nature in Hushe has been its individualizing effects. In Hushe, for example, the symbolic value attached to being a good hunter has diminished. Historically, village members recognized a free right to hunt within village lands. This right was a constitutive part of what it was to be a village member and, as I have pointed out above, important in a variety of symbolic ways (e.g. distribution of meat and sharing of liver, heart and kidneys). Wildlife, while it resided on community commons, was available to community members, subject to household need, the ability to acquire a weapon and the ability to actually go hunting in the face of labour constraints or other communal responsibilities. The distribution of capital, however, as it flows from the proceeds of the sale of trophy hunting licences, effectively curtails that right, and justifies that curtailment by appealing to other egalitarian and environmentalist values. It also makes resistance a more difficult practice because of the modifications in the use-meaning of wildlife and the alterations it introduces into village social relations and social structure. Indeed, through the alteration of social relations, the deployment of state subjectivities penetrates to the level of the village. The subsistence hunter, for example, is no longer simply a criminal in the eyes of the state but also in the eyes of those of his neighbours who most stand to gain economically and politically from trophy hunting or increased adventure tourism. New grounds for suspicion are introduced into the community through the privatization and commodification of a resource. Now, whenever someone leaves the village at an odd time or with a firearm, there is an element of suspicion that they may be engaged, not in an act of material and symbolic value, but in an act of theft against 'the community'. The 
use of capital as an incentive for protection is also likely to result in stiffer penalties for poaching, particularly given the redefinition of wildlife as community property. Poaching, now, is not just a crime against nature, or against the property of the maharajah or the state, but a crime against 'the community' and, of course, a crime against capital - the capital of the hunter who will pay to kill the animal that has been 'poached'. ${ }^{80}$ These penalties effectively criminalize subsistence hunters while protecting the interests of wealthy foreign hunters. This is one example of how the intervention of international conservation NGOs and sport trophy hunters, in the act of redefining wildlife, redefines nature-society relations. ${ }^{81}$ A discourse of global ecology also redefines wildlife as property in ways that increase the legitimacy of the global trophy hunter's claim to a right of access. While the trophy hunter is interested in little more than using money to purchase the right to hunt which he cannot gain through other means such as access to territory based on community membership, by purchasing his right to kill, he is, within the sanctioning terms of a discourse of global ecology, protecting global property. This accords with the ways in which discourses of globalism deterritorialize local property and property rights, and reterritorialize them in global terms. It also derives from a neo-liberal contention that obstacles which prevent capital from accessing property need to be levelled if 'development' is to be achieved. ${ }^{82}$

This process of de- and reterritorialization is reliant on specific mechanisms that allow the global hunter access to wildlife in 'remote' places of the world, while restricting local access to those same resources. And those mechanisms derive from the environmental brokerage role that international conservation agencies play in translating and transmitting the knowledge involved in the production of a discourse of global ecology. This brokerage role is facilitated by agreements with power as it resides in statist institutions - such as national governments that claim ownership of resources but are willing to cede it to the highest bidder - and as it exists in local communities. ${ }^{83}$ But it is also facilitated by the ontology that constitutes the foundation of a discourse of global ecology, the very discourse that legitimates actions such as international trophy hunting for conservation. It would be difficult, for example, to legitimate international sport trophy hunting without the ontology of a discourse of global ecology, primarily the existence of a 'global commons' and the 'biodiversity' that resides within that global commons. Nor could it be maintained without the representation of a 'rapacious native', who has neither the skills nor the inclination to manage that biodiversity. Foreign hunters claim to be struggling against the rapacious tendencies of local villagers who are taking advantage of a common resource. Leaving the responsibility of 'wildlife management' to locals, they claim, will lead to extinction. Against local control, hunters are able to deploy not simply their own discursive formations but those of international environmental organizations. These organizations position local residents as exploiters who need to be curtailed in their killing of wildlife. One way to achieve this goal and gain access to local hunting grounds is to reconfigure wildlife not simply as local property but as global property, as a global resource that everyone in the world has a duty to protect. If wildlife can be identified as a global resource, the moral claim can be made that it should be cared for and preserved in the interests of a global citizenry. Within this discourse the local 
subsistence value of game for individual households becomes negligible compared to its recreational and aesthetic significance to a wider community of global stakeholders. Yet agreements grounded in this discourse - that protect ibex for the 'many' (the globe) against the 'few' (villagers) - are essentially class agreements that implement protection for the benefit of the wealthy. In effect, such agreements take local land and resources and create a global property, in our case a global hunting ground, accessible only to a global elite and those few locals who happen to guide them. This is, in effect, the creation of a new private hunting ground for a new global elite. It is also the creation of a new 'nature' that reflects the interwoven interests of the state, science, and capital. Here, for example, is a description of how capital, in the form of new tourism initiatives, realizes benefits from agreements that are meant to protect biodiversity:

The local wildlife of Hushe is Pakistan's richest - the Asiatic ibex, the snow leopard, the wolf, and the fox being some of them. Life in parts of the Hushe Valley hasn't changed in centuries and can still be seen set against the rugged snow cloaked peaks and cobalt blue skies. Its [sic] hard to imagine a more majestic setting.... You will ... spend $4 / 5$ days accompanying IUCN and local Village Wildlife Guides on their monitoring of wildlife in this conservation area. Local community awareness for conservation is constantly being raised - their rich environment is their biggest asset when managed locally and sustainably. Since the completion of an ecotourism survey report in 1996, IUCN has been working with the Hushe community to raise awareness, targeting both locals and visitors, about the environmental impacts associated with unregulated tourism. Your participation in this programme will practically and financially help to support the local environmental and community based efforts mentioned. ${ }^{84}$

Nature, reterritorialized through the capacity-building interventions of global institutions, is also nature reproduced as spectacle that supports the need of adventure tourism for new markets. Of course, there are also symbolic goals involved here. Not only do the interests of capital gain through the re-inscription of nature in global terms, but the global institutions responsible for that process benefit through the creation of a new means of circulating a new knowledge of people and place - a knowledge of a people and place 'raised' through the development of a capitalized nature.

\section{Conclusion: globalism, ecology and discipline}

Despite assertions that a discourse of global ecology is a recent construction, a number of threads connect Roosevelt's web of romance, science and nationalism with the introduction of sport trophy hunting in Hushe in the late 1990s. Both rely on: (i) conceptions of wildlife as a symbolic and a material resource that exists as part of a global commons, itself defined through the knowledge-producing mechanisms of a rationalist science; (ii) claims on wildlife as property; and (iii) the primacy of science and conservationist goals as the legitimating rationale for the hunt. In both cases, the logic of what Escobar has called 'capitalized nature' runs through the historical narrative from Roosevelt (and before) to the present day. ${ }^{85}$ No doubt there are differences between the two 'projects'. 'Development', for example, was not part of the rhetoric deployed in the legitimation of Roosevelt's expedition. And although science is a legitimizing rhetorical device in both scenarios, science has to a degree transcended 
nationalist frames and assumed international dimensions, particularly through the rise of institutional ecologism. ${ }^{86}$ Through the ability of international institutions to access global markets, local ecologies are brought into a sphere of power relations whereby they are managed by the intersecting demands of the state, science, global capital (concentrated in specific centres of accumulation) and a localized subsistence agricultural economy. This ability is, of course tied into other forces of globalization. It is the capital of those in dominant positions within the global economy which provides the ability to transcend the vagaries of space through technology so that such individuals can hunt ibex, and which provides international institutions with the capacity for intervention and the ability to attempt to redefine 'nature'. In many ways, then, the exchange value of ibex that contributes to the redefinition of local ecologies is directly linked to the technologies that intensify processes of globalization. Trophy hunting also entrenches a set of labour relations. Like a reworked colonialism, the variety of environmentalism that supports this capitalization of nature relegates villagers not to the role of 'managers' but to that of servants (shikaris), forbidden to hunt, whose role is simply to show the wealthy where and how to find the beasts they seek. Hunters and the international institutions which support their activities through the rhetoric of 'sustainable use initiatives' are able to do this because of global inequities, and because of the commodity fetishism of international trophy hunting. All of these institute new relationships between people, social institutions and 'nature' in the village by tying them into an ecology defined not within the context of local use meanings but through discourses of globalism. This new 'management regime', and the altered social relations it masks, represent some of the localized material consequences of a discourse of global ecology.

The combined operation of the interests I have described in this paper is not simply a form of innocuous intervention. Rather, it can be seen as a new form of governance that has accompanied the rise of environmentalism. Luke has referred to this as 'green governmentality', which has been coincident with the ways in which 'the environment, particularly the goals of its protection, has become a key theme of many political operations, economic interventions and ideological campaigns to raise public standards of collective morality, personal responsibility and collective vigour'. ${ }^{87}$ This form of green governmentality, however, relies on a discourse that 'tells us that today's allegedly unsustainable environments need to be disassembled, recombined and subjected to the disciplinary designs of expert management'. ${ }^{88}$ The example presented in this paper is but one case among many where assertions of unsustainability and a discourse of global ecology are used as the lever through which to enter a community in order to apply expert designs to a local environment. The goal here is to redirect a local environment to fulfil the ends of new scripts - in this case the script of biodiversity protection and the international managerial and administrative directives that accompany it. For this redirection to occur, however, existing means of policing ecological spaces must be constructed as ineffective. Old modes of domination must be replaced. New instrumental rationalities need to be put in place. And it is the capitalization of nature, and consequent attempts to instil a 'new set of environmental values' through projects such as 'Maintaining biodiversity in Pakistan with rural 
community development', which subject local ecologies to global management procedures. Trophy hunting, in effect, serves as Weberian 'booty' through which the realization of nature as capital acts as a means to extend the reach of a western scientific rationale for environmental management into local spaces - resulting in the creation of trans-local ecologies. ${ }^{89}$ It is still too early to see what kinds of 'nature' will emerge through these processes. It is possible that resistance will emerge in places like Hushe as it has in response to the initiatives of state, capital and biodiversity protection in other areas of the Karakoram and in Africa. ${ }^{90}$ What is certain is that the structuring terms of a discourse of global ecology and the transnational, governmental and capitalist institutions that produce and deploy it are becoming more pervasive in their attempts to redefine 'nature', property and space in ways that convert local into translocal ecologies. Listen closely and you can still hear the words of Kipling and Roosevelt faintly echoing in the textual chambers of international conservation organizations. The 'rapacious native' persists, leaving conservation 'experts', science, and foreign hunters in the position of knowing best how to 'deal with Orientals'.

\section{Acknowledgements}

I am indebted to people in Hushe and Askoli, Pakistan, for their openness and hospitality over the years. I also owe thanks to a number of people who have encouraged, read, commented on, or contributed to the shape of this paper including: Tom Bassett, Ashley Dawson, David Demeritt, Michele Dominy, Paul Greenough, Rebecca Johns, Tad Mutersbaugh, Paul Robbins, K. Sivaramakrishnan and Holly Wardlow. Thanks also to participants in the Critical Development Studies Seminar at the University of Iowa, including Amita Bavaskar, Jim Ferguson, Stacy Leigh Pigg, Vasant Saberwal, Paige West and Charles Zerner, who all offered useful comments and suggestions. Thanks also to Don Mitchell and anonymous reviewers for their helpful comments. I accept responsibility for any errors or omissions that remain.

\section{Notes}

1 T. Roosevelt and K. Roosevelt, East of the sun and west of the moon (New York, Scribner's, 1926), p. 2.

2 Roosevelt quotes Kipling's poem 'The feet of young men'.

3 Roosevelt and Roosevelt, East of the sun, p. 4.

${ }^{4}$ Cf. A. Bloom, Gender on ice: American ideologies of polar exploration (Minneapolis, University of Minnesota Press, 1994).

5 Roosevelt and Roosevelt, East of the sun, p. 5.

6 Ibid., pp. 7-8.

7 J.A. McNeely, Economics and biological diversity: developing and using economic incentives to conserve biological resources (Gland, Switzerland, IUCN, 1988); International Institute for Environment and Development, Whose Eden? an overview of community approaches to wildlife management (London, Overseas Development Administration, 1994); C.C. Gibson 
and S.A. Marks, 'Transforming rural hunters into conservationists: an assessment of community-based wildlife management programs in Africa', World development 23 (1995), pp. 941-57; C.H. Freese, ed., Harvesting wild species: implications for biodiversity (Baltimore, Johns Hopkins University Press, 1997); D.M. Lewis and P. Alpert, 'Trophy hunting and wildlife conservation in Zambia', Conservation biology 11(1997), pp. 59-68.

8 Cf. D. Cooper, Governing out of order: space, law and the politics of belonging (London, Rivers Oram Press, 1998).

9 This deployment of scientific authority in relation to wildlife has not received the same scrutiny from historians and philosophers of science as from other branches of science.

${ }^{10}$ K. I. MacDonald, 'Rationality, representation and the risk mediating characteristics of a Karakoram mountain farming system', Human ecology 26 (1998), pp. 287-322.

11 Formerly IUCN (the International Union for the Conservation of Nature).

12 In all, the Government of Pakistan approved 15 permits for the Northern Areas.

13 R. Garstang, pers. comm.

14 Convention on International Trade in Endangered Species of Wild Fauna and Flora, Resolution of the conference of the parties (10th Meeting of the Conference of the Parties, Harare, Zimbabwe, 9-20 June 1997).

15 Aslam Hushepa, pers. comm.

16 Government of Pakistan, Maintaining biodiversity in Pakistan with rural community development: PCII (Islamabad, Environment and Urban Affairs Division, n.d.)

17 Ibid., p. 2.

18 Ibid.

19 R Galpin, 'Hunting the rare ibex' (Washington, DC, National Public Radio, Living on Earth, 9 Apr. 1999, transcript); available at http://www.loe.org/archives/000409.htm\#feature2

${ }^{20}$ Humane Society of the United States (1995), Big game, big bucks: the alarming growth of the American trophy bunting industry (Washington, DC, HSUS, 1995). This increase can also be tied to the loosening of regulations restricting the import of game into North America. The consequent ability to 'own' and display the trophy may well increase the desire of hunters to travel abroad.

21 The government's share of revenue from trophy hunting, if it so chooses, can also be put into ongoing conservation programmes. This is one reason why trophy hunting receives support from international conservation organizations. Such programmes in Africa, for example, commonly have a proviso that monies raised from trophy hunting (which fall within government control) be used for conservation programmes: M.L. Corn and S.R. Fletcher, African elephant issues: CITES and CAMPFIRE. Congressional Research Service Report for Congress (Washington, DC, Committee for the National Institute for the Environment, 1997).

22 Proponents of limited trophy hunting of ibex, for example, include the International Snow Leopard Trust, which supports it on the basis of the potential to increase the availability of prey for snow leopard and reduce the motivation to attack livestock. In this way biodiversity is used rhetorically to extend the interest of capital in control over 'natural resources'.

23 D. Butz, 'Orientalist representations of resource use in Shimshal, Pakistan, and their extradiscursive effects', in I. Stellrecht, ed., Karakoram-HinduKush-Himalaya: dynamics of change (Cologne, Rudiger Koppe, 1999).

24 World Bank, The Aga Khan Rural Support Program in Pakistan: a second interim evaluation (Washington, DC, World Bank Operations Evaluation Department, 1990), p. 35.

25 This, however, is only an 'official' representation. There is, for example, an alternative construction of space that centres on the assertion that the wholesome conditions of life in part of the Karakoram contribute to the long and healthy lives of inhabitants. This discourse gave 
rise to and was reproduced through a host of texts written in the 1950s and 1960s that depicted the lifestyle of the 'healthy Hunzas'. See Dolphin, 'The discursive construction of Hunza, Pakistan in travel writing: 1889-1999' (MA thesis, Department of Geography, Carleton University, Ottawa, Canada, 2000). Also, despite these pronouncements of an inadequate environment, some research has highlighted the remarkable production potential of cultivation in Karakoram villages. See P.T.S. Whiteman, 'Mountain agronomy in Ethiopia, Nepal and Pakistan', in N.J.R. Allan et al., eds, Human impacts on mountains (Totowa, NJ, Rowman and Littlefield, 1988); K.I. MacDonald, 'The mediation of risk: ecology, society, and authority in a Karakoram mountain community' (PhD dissertation, Department of Geography, University of Waterloo, Waterloo, Canada, 1995).

26 Given the major territorial dispute between India and Pakistan over the past 50 years, any government-supported infrastructure development in the region has been primarily for military rather than economic purposes. An example of such investment was the completion of the Karakoram highway in 1976. This land route, however, provided access to the Northern Areas for adventure tourists and, as a partial spin-off of tourism, large development and international conservation organizations. See H. Kreutzmann, 'The Karakoram highway: the impact of road construction on mountain societies', Modern Asian studies 25 (1991), pp. 711 36; H. Kreutzmann, 'Challenge and response in the Karakoram: socio-economic transformation in Hunza, Northern Areas, Pakistan', Mountain research and development 13 (1993), pp. 19-39.

27 A. Escobar, 'Cultural politics and biological diversity: state, capital and social movements in the Pacific coast of Columbia', in D. Lloyd and L. Lowe, eds, The politics of culture in the shadow of capital (New York, Routledge, 1997), p. 206.

28 This expansion has experienced periodic setbacks, and tourism in Pakistan always rests on a fickle economic surface. The first Gulf War, for example, caused a significant reduction in tourist visits to northern Pakistan, as did the Kargil crisis of 1999.

29 K. I. MacDonald and D. Butz, 'Investigating portering relations as a locus for transcultural interaction in the Karakoram region of northern Pakistan', Mountain research and development 18 (1998), pp. 333-43.

30 Despite the increasing access of the Karakoram to expeditions and tour groups, the area continues to be represented as remote. Tourists are promised the opportunity to visit people and places rarely experienced by outsiders. The glossy brochures of travel agencies also offer travellers a look back in time at 'places unchanged for centuries', evoking the sentiment associated with some distant past. This is not a new trope. Indeed, it was deployed by Roosevelt and Roosevelt: 'These caravan routes are practically the same today as they were when a few adventurous Europeans pushed east over them in the late Middle Ages' (East of the sun, p. 2). These representations often result in antagonism between tour groups when they find that promises of an exclusive and unique experience cannot be maintained in practice.

31 K. MacDonald, 'Rationality, representation and the risk mediating characteristics of a Karakoram mountain farming system', Human ecology 26 (1998), pp. 287-321.

32 A. Gupta, Postcolonial developments: agriculture in the making of modern India (Durham, NC, Duke University Press, 1999).

33 K.I. MacDonald, "Where the wild things are: capitalized nature and the cultural politics of "community" in northern Pakistan', paper presented at the Annual Meeting of the American Anthropological Association, Washington, DC, Nov. 2001 (copy available from the author).

34 The emergence of heavily capitalized tourism in northern Pakistan has coincided with a rise in the interest of conservation organizations in the region. There are a number of reasons for this relational dynamic. One centres on the way in which space is brought under the sway of 
global institutions. As international capital converts local spaces into international spaces of consumption, these same spaces become the subject of conservation efforts, and conflicting interests often compete over claims to be operating in the interest of conservation. This relationship can be examined in northern Pakistan through recent efforts to create a number of national parks in the region. These efforts have not been unproblematic, and the struggle for space is evident in the tensions between villagers and government/NGO representatives surrounding the establishment and management of protected areas in the Northern Areas of Pakistan. See G. Schaller, Stones of silence: journeys in the Himalaya (New York, Bantam, 1979); B. G. Bell, ed., Proceedings of the International Workshop on the Management Planning of Khunjerab National Park June 7-16, 1989 (Washington, DC, US National Park Service, Office of International Affairs, 1991); P. Wegge, 'Khunjerab National Park in Pakistan: a case study of constraints to proper conservation management', in P. Wegge and J. Thornback, eds, Proceedings of conservation of mammals in developing countries (Rome, Fifth Theriological Congress, 1989); A.J. Knudsen, 'Nature conservation in northern Pakistan: case studies from Hunza, with special reference to the Khunjerab National Park', in O. Bruun and A. Kalland, eds, Asian perceptions of nature (Copenhagen, Nordic Institute of Asian Studies, 1992); K.I. MacDonald, 'A critical review of the Central Karakoram World Heritage Site workshop', in S. Fuller, ed., Proceedings of the Central Karakoram World Heritage Site workshop (Karachi, Pakistan, IUCN-World Conservation Union, 1995), pp. 29-44; J. Mock, 'Objects of desire in the Northern Areas', Himal 8 (1995), pp. 8-10; J. Mock and K. O'Neill, Survey on ecotourism potential in the biodiversity project area (Islamabad, World Conservation Union (IUCN), 1996); J. Mock, 'Mountain protected areas in northern Pakistan: the case of the national parks', in E. Bashir, ed., Proceedings of the Third International Hindukush Cultural Conference (Karachi, Oxford University Press, forthcoming); D. Butz, 'Resistance, representation and third space in Shimshal village, northern Pakistan', ACME 1 (2002), pp. 15-34.

35 This is a contested history at best. IUCN, for example, is not an organization that emerged out of the 'new' environmentalism of the post-Apollo age. Rather, it traces its institutional roots to 1948, and can be genealogically connected to imperialist environmental concerns in the form of the Society for the Preservation of the Fauna of the Empire. This organization was founded in 1903 by a small group of big-game hunters who sought to promote the establishment of wildlife preserves in Africa and Asia. Ironically, this historical pedigree tends to give groups like IUCN-World Conservation Union more credibility than some more recent organizations tinged by the radical environmental politics of the 1960s. See R.P. Neumann, 'Dukes, earls, and ersatz edens: aristocratic nature preservationists in colonial Africa', Environment and planning D: society and space 14 (1996), pp. 79-98.

36 D. Takacs, The idea of biodiversity: philosophies of paradise (Baltimore, Johns Hopkins University Press, 1996), p. 75.

37 M. Flitner, 'Biodiversity: of local commons and global commodities', in M. Goldman, ed., Privatizing nature: political struggles for the global commons (New Brunswick, NJ, Rutgers University Press, 1999), pp. 144-66.

38 IUCN, for example, has positioned itself as a broker between national governments and UNESCO in the recommendation of locations for World Heritage Site designation. This process has not gone uncriticized. Guha, for example, notes significant cleavage between an international environmentalism designed in 'the West' and marketed around the world to receptive state governments, and an environmentalism that emerges from specific settings in the so-called 'third world' and is usually hostile to state governments. R. Guha and J. Alier, Varieties of environmentalism: essays north and south (London, Earthscan, 1998). 
39 A. Jamison, 'The shaping of the global environmental agenda: the role of non-governmental organisations', in S. Lash, B. Szerszynski and B. Wynne, eds, Risk, environment and modernity: towards a new ecology (London, Sage, 1996), pp. 224-45. See also P.J. Taylor and F.H. Buttel, 'How do we know we have global environmental problems? Science and the globalization of environmental discourse', Geoforum 23 (1992), pp. 404-16; Escobar, 'Cultural politics'.

40 Jamison, 'Global environmental agenda', p. 224.

41 M. Goldman, 'Inventing the commons: theories and practices of the "commons" professional', in Goldman, Privatizing nature, pp. 20-53.

42 Jamison, 'Global environmental agenda', p. 226.

43 For example, the Pakistan National Conservation Strategy, drafted in 1991, which serves as an environmental strategy and action plan, and guides environmental policy in the country, was written with the advice of consultants from IUCN, WWF and the Canadian International Development Agency (CIDA). Since its production, this document has framed the conduct of internal environmental research and policy development in Pakistan. Its preface expresses the basis of a discourse of global ecology: 'Pakistan, like much of the world, increasingly views environmental degradation as global in scope; the actions of one country can inadvertently affect the environmental health of another. Indeed, even environmental problems that appear to be purely national in dimension are often linked to worldwide trends, often in the context of the economic chasm between North and South': Government of Pakistan and IUCN-World Conservation Union, The Pakistan National Conservation Strategy: where we are, where we should be and how to get there (Islamabad, Environment and Urban Affairs Division, 1992), p. 1. This document stems from the World Conservation Strategy (WCS) established by IUCN/ WWF in 1980 which called for all countries to produce a national conservation strategy. A measure of the importance of biodiversity as a foundational element in discourses of global ecology is implicit in the title of the document that has superseded the WCS: Global biodiversity strategy: guidelines for action to save, study and use earth's biotic wealth sustainably and equitably (Washington, DC, World Resources Institute/IUCN/United Nations Environment Program, 1992).

44 Cf. W.N. Adger et al., 'Advancing a political ecology of global environmental discourses', Development and change 32 (2001), pp. 682-715.

$45 \mathrm{~J}$. Ahmed and S. Hussain, Community-based natural resource management in northern Pakistan (paper presented at the International Workshop on Community-Based Natural Resource Management, Washington, DC, 10-14 May 1998); available at http://www.worldbank. org/wbi/conatrem/Pakistan-Paper.htm

46 Ibid., p. 1.

${ }^{47}$ Ibid., p. 3. Note the unproblematic homogeneous way that these social groups of 'community', 'government institutions' and 'NGOs' are represented, as if the interests of the individuals who constitute these groups were all equitable and without conflict. I will return to this problem below.

48 This recognition of criteria through which to define success already contradicts the assertion that local people are in 'the driving seat'.

49 This is an example of how expert-based social intervention uses the mechanisms established by the AKRSP as a route of access to villages, and as the mechanisms through which to introduce new technologies, innovations, or programmes.

50 Ahmed and Hussain, Community-based natural resource management, p. 8. We can see here a problem from an ecosystem management standpoint. Rather than managing a set of 
resources holistically, or within an understanding of a local environmental system, management plans focus on the management of species or habitats in isolation.

Government of Pakistan, Maintaining biodiversity, p. 5 (emphasis added).

52 MacDonald, 'Where the wild things are'.

53 P. Goodwin, "Hired hands" or "local voices": understandings and experience of local participation in conservation', Transactions of the Institute of British Geographers 23 (1998), pp. 481-99; R.A. Schroeder, 'Geographies of environmental intervention in Africa', Progress in buman geography 23 (1999), pp. 359-78; J.L. Hough, 'Institutional constraints to the integration of conservation and development: a case study from Madagascar', Society and natural resources 7 (1994), pp. 119-24; A. Agrawal and C.C. Gibson, 'Enchantment and disenchantment: the role of community in natural resource conservation', World development 27 (1999), pp. 629-49; A. Knudson, 'Conservation and controversy in the Karakoram: Khunjerab National Park, Pakistan', Journal of political ecology 6 (1999), pp. 1-30.

54 This emphasizes the need for ethnographies of global institutions in order to gain a better understanding of how they construct or adapt knowledges of their subjects. See J.P. Brosius, 'Analyses and interventions: anthropological engagements with environmentalism', Current anthropology 40 (1999), pp. 277-309; P. West, 'Environmental NGOs and the nature of ethnographic inquiry', Social analysis: journal of cultural and social practice 45 (2001), pp. $55-77$.

55 Government of Pakistan, Maintaining biodiversity, p. 23.

56 Ibid., p. 23.

57 Ibid., p. 1.

58 There are grounds for believing that numbers below what might be expected given the extent of habitat could well be due to decimation under the British administration.

59 Hushe villagers have opened new pastures over the past four years, but that is due to pressures placed on old pastures by expanding, externally driven, adventure tourism activities. Women, the primary pastoralists, feel unsafe occupying pasture lands that are crossed by trekking and climbing expeditions, and have encouraged the development of new pastures. This, however, does not amount to expanded pasture use, but to relocation driven by the resource demands of new capital interests.

60 K.I. MacDonald, 'Population changes in the upper Braldu valley, Baltistan, 1900-1990: all is not as it seems', Mountain research and development 16 (1996), pp. 351-66.

61 Government of Pakistan, Maintaining biodiversity, p. 2.

62 Ibid., pp. 23-24.

63 Escobar, 'Cultural politics'.

64 Ibid., p. 203.

65 Much of this contest revolved around the significance of hunting for the construction of British Indian masculine identity. Kashmir was produced in the popular imagination as a place where ideals of masculinity were constructed and displayed, where young and old men demonstrated the prowess of strength or the virtue of wisdom. See J. Keay, When men and mountains meet: the explorers of the western Himalayas 1820-1875 (London, Murray, 1977); J. Keay, The Gilgit game: the explorers of the western Himalayas, 1865-1897 (Oxford, Oxford University Press, 1990); K.I. MacDonald, 'Kashmir', in J. Speake, ed., The literature of travel and exploration: an encyclopedia (London, Fitzroy Dearborn, 2003).

66 R.H. Thyacke, In quest of game: A sportsman's manual for game shooting in Kulu, Laboul and Ladak to the Tso Morari lake with notes on shooting in Spiti, Bara Bagahal, Chamba and Kashmir (Calcutta, Thacker, Spink, 1927), p. 55.

67 W.R. Lawrence, The valley of Kashmir (Oxford, Oxford University Press, 1895). 
68

69 Ibid., p. 107.

70 Such as the Society for the Preservation of the Wild Fauna of the Empire (SPFE), established in 1903 (which claimed to be the world's first international wildlife conservation organization), and Roosevelt's Boone and Crockett Club, established shortly afterward. Both these associations, however, were concerned, not with wildlife per se, but with threats to the ability of an elite class to secure exclusive hunting grounds.

71 M. Davis, Ecology of fear: Los Angeles and the imagination of disaster (New York, Vintage, 1998), p. 226.

${ }^{72}$ J. Arbuthnot, A Trip to Kashmir (Calcutta, Thacker, Spink, 1900), pp. 25-6. Just as colonial hunters were reacting in India against challenges to their activities in Britain and modifying local ecologies in the process, so too it would seem that international trophy hunters modify local ecologies around the world in reaction to challenges to their activities at home.

73 Neumann, 'Dukes, earls and ersatz Edens', p. 87.

${ }^{74}$ Lawrence, Valley of Kashmir, p. 107.

75 Though they could be provided with guns while they were in the employ of a licensed hunter.

76 R.C. Arora, In the land of Kashmir, Ladakh and Gilgit: with their history, places of interest, routes, walks, and exhaustive information for the guidance of visitors to Kashmir, Ladakh, Gilgit, Astor, Skardu, etc. (Aligarh, Unique Literature Publishing House, 1940), p. 285.

77 It is extremely difficult to provide an accurate sense of the effect of Raj-era hunting on the faunal populations of Kashmir. Hunting records are tied up in the state repositories in Srinagar and Jammu and it is difficult to gain access because of the recent troubles in Indian-held Kashmir. If the photographs and counts in the 'bag books' are any representative indication, considering that a significant minority of hunters actually wrote tales of their hunts, the damage was severe, and is certainly tied to population dynamics in the region today.

78 Galpin, 'Hunting the rare ibex'.

79 Cf. J. Breman, The shattered image: construction and deconstruction of the village in colonial Asia (Dordrecht, Foris, 1989).

80 What is being poached, of course, is the trophy hunter's ability to kill that animal because a subsistence hunter has already claimed it.

81 Although it is early yet to speculate, it is possible to envision ecological consequences of these schemes. As trophy hunting was instituted as an agreement with 'the community', it must occur on land controlled by the village. Ibex, however, are a fugitive resource and considered free by other local communities. A potential problem then arises when a contractual agreement involving a spatially fixed resource (land) also applies to an object of desire that is actually a mobile resource (ibex). The possibility of 'escape' from community control, and thus a potential loss of revenue, creates a financial incentive to interfere with the migration patterns of wildlife so that they remain on the land, potentially degrading its quality. In addition, the benefits accruing to individual villages from what amounts to the private sale of a 'resource' considered to be free also has significant potential to mobilize hostility between neighbouring villages, similar to that seen during the enclosure movements in Britain and North America.

82 Witness opposition to protection of public lands in the United States; Multilateral Agreement on Investment or World Trade Organization opposition to attempts to 'limit' the revenue generating potential of investments; or the opposition of International Monetary Fund Structural Adjustment Policies to the public management of lands.

83 Conservation NGOs rarely seem to ask questions of power. They are rarely familiar with the decision-making structures of communities, modes of legitimating authority, power relations 
and the trajectories of power that direct the benefits and damages of interventions. Often there is an apparent assumption that authority speaks for all. And rarely is there recognition that the promise of capital provides power to segments of the community that can radically redefine access to resources.

84 Discovery Initiatives, 'Pakistan-Northwest Frontier Province' (Ecotourism advertisement http://www.ecotour.org/destin/places/DISCOV3.HTM)

85 Escobar, 'Cultural politics'.

86 A. Bramwell, Ecology in the twentieth century: a history (New Haven, CT, Yale University Press, 1989).

87 T.W. Luke, 'Environmentality as Green governmentality', in E. Darier, ed., Discourses of the environment (Oxford, Blackwell, 1999), p. 122.

88 Ibid., p. 142.

89 By 'trans-local ecologies' I refer to the material human-environmental relations that emerge through the spatial reach of global institutions and capital into the everyday social and ecological relations of communities previously removed, to varying degrees, from those forces.

90 See D. Butz, 'Resistance, representation and third space'; A. Knudsen, 'State intervention and community protest: nature conservation in Hunza, Northern Pakistan', in O. Bruun and A. Kalland, eds, Asian perceptions of nature (Copenhagen, Nordic Institute of Asian Studies, 1992); R.P. Neumann, 'Local challenges to global agendas: conservation, economic liberalization and the pastoralists' rights movement in Tanzania', Antipode 27 (1995), pp. 363-82. 